\title{
マイクロ複雑形状の超精密巧妙加エ*
}

\author{
西山 諒*1, 中本圭一 ${ }^{* 2}$, 石田 徹 ${ }^{* 3}$, 竹内芳美 ${ }^{* 4}$
}

\section{Ultraprecision Dexterous Machining of Micro Complex Shape}

\author{
Ryo NISHIYAMA*1 , Keiichi NAKAMOTO, Tohru ISHIDA and Yoshimi TAKEUCHI \\ ${ }^{* 1}$ Department of Mechanical Engineering, Osaka University \\ 2-1, Yamadaoka, Suita, Osaka, 565-0871, Japan
}

\begin{abstract}
Corresponding to diverse consumer needs, high-mix and low-volume production is becoming more important. Unique products matching consumer's sensitiveness tend to be welcome. These products will be something like art and craft products, which require skill and experience to create. This study deals with 5-axis control tool path generation to dexterously and efficiently create such craft-like microshapes, while maintaining the quality. Concerning 5-axis control machining, the way of using ball end mills is generally employed. However, it needs a lot of time to get high quality surface. To solve this problem, a side cutting edge of the ball end mill is positively utilized with its tool axis parallel to the ruled surface. Therefore, a new CAM system is developed to detect the surface to be machined with the side cutting edge, and to generate the collision-free tool paths between the tool and the workpiece. The effectiveness of the developed CAM system is experimentally confirmed by creating a tiny Möbius ring.
\end{abstract}

Key Words : Dexterous Machining, Ultraprecision Micro Milling, CAM, 5-Axis Control Machine Tool, Ball End Mill Side Edge Cutting

\section{1. 緒言}

近年，消費者のニーズの多様化に伴い，生産の分野では多品種少量生産が主流となっている．このため，機械 加工においては, 効率よく加工寸ることが要求されている. また, 工業製品はなんらかの機能を有しており，そ の機能を実現するために，機能を司る形状を単純な要素に分割し，それらを組み合わせて製造される．しかし， これからは個人の感性に合わせた個性的な製品形状が望まれることになると考えられる．このような消費者の要 求を満たすためには，複雑な形状を分割することなくそのまま処理し，芸術品や工芸品のような高い価值を有す るものを創成する技術が必要と思われる. 本研究では, 今までの高品質で高生産性を目指寸加工法に加え、この ような高付加価值を目指した加工法のことを巧妙加工と呼ぶことにする．通常，複雑な形状をもつ製品を加工す る際は，プロセスの決定に熟練した技能者のノウハウが求められるが，これらを機械加工で創成するためにはノ ウハウをアルゴリズム化し，汎用性の高いCAM システムを開発する必要がある.

巧妙加工に関してはすでに鎖形状 ${ }^{(1)}$ や複数の曲がり円柱からなる複雑形状 ${ }^{(2)}$, 入れ子を有する複雑形状 ${ }^{(3)}$ の巧妙 加工を報告してきた．これらは旋削加工とフライス加工をともに行える複合加工機を用いて加工していたが，本

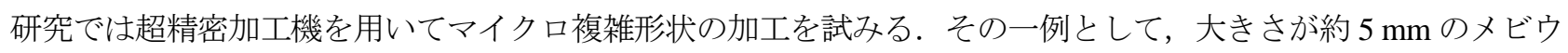
スの輪を創成する，その際，加工時間を大幅に短縮するために，ルールドサーフェスと呼ばれる自由曲面に対し ては回転工具の側面切れ刃を用いて仕上げ加工を行うという特色のある加工法を適用する.

\footnotetext{
* 原稿受付 2012 年 1 月 12 日

*1 大阪大学大学院工学研究科（广565-0871 大阪府吹田市山田丘 2-1)

*2 正員, 東京農工大学大学院工学研究院（干184-8588 東京都小金井市中町 2-24-16）

*3 正員, 徳島大学大学院ソシオテクノサイエンス研究部 (T770-8506 徳島県徳島市南常三島町 2-1)

${ }^{* 4}$ 正員, フェロー, 中部大学工学部（广487-8501 愛知県春日井市松本町 1200）

E-mail: takeuchi_yoshimi@isc.chubu.ac.jp
} 


\section{2. 側面切れ刃を用いる加エ}

微細な複雑形状を巧みに加工するということで，本研究では超精密マイクロ巧妙加工と呼ぶ分野を開拓しよう とするものである. 超精密マイクロ加工としては今までに自由曲面をもつ複雑な形状を加工してきだ(4)(8)が，こ れらは 5 軸制御加工によって創成され，そこでは干渉を巧みに回避しながら工具経路が生成されている，それら も一種の巧妙加工といえなくもないが, 本研究でいう巧妙加工は, 「巧みさ」をいかにシステムに取り組むかにあ る. 本研究で加工対象としたメビウスの輪はルールドサーフェスからなるため, ボールエンドミルを用い, 干渉 回避をしながら 5 軸制御加工を行うことになる. その際，加工の効率を上げるために積極的に工具側面切れ刃を 利用し，それができない場合には先端切れ刃であるボール部を用いるという工夫をしている．超精密マイクロ加 工を目指寸ために，加工機は 5 軸制御可能な超精密加工機を用い，加工物の大きさは $5 \mathrm{~mm}$ としている.

さて, 5 軸制御加工機は, X, Y, Z の並進駆動 3 軸に回転駆動 2 軸を加えたもので, 加工物に対してあらゆ る工具姿勢をとれるという特徵がある. これにより, 加工面品質の向上, 段取り替えの省略などが可能になる. しかし, 図 1(a)のように, 仕上げ加工に広く用いられているボールエンドミルの先端切れ刃を用いた場合では, 円弧の一部で加工をするため, ピックフィード方向には工具が離散的に移動することになり, 波状凹凸（カスプ） を生じる. 工具半径を $r$, ピックフィードを $P_{f}$, とするとカスプ高さ $h$ は以下の式で近似的に表される.

$$
h \approx \frac{P_{f}^{2}}{8 r}
$$

この式から分かるように，カスプの高さはピックフィードの 2 乗に比例するため, 加工面品質を向上させようと すると, 小さいピックフィードで加工を行う必要がある. しかし，ピックフィードを小さくすると工具経路が長 くなり，加工時間が延び，効率が低下寸る.

一方，図1(b)のように，回転工具の側面切れ刃を用いた加工 ${ }^{(9)(10)}$ では，工具の送り速度に対して工具の主軸回 転数が非常に大きいため, 従来のピックフィード方向のカスプは生じず, また一度に広い面積を加工できるので, 加工時間を短縮することが可能となる.

そこで，ルールドサーフェスを見分け，側面切れ刃が利用できる場合には高効率で加工し，使用できない 場合はボール部の先端切れ刃を適用寸るという器用な加工法を提案する. メビウスの輪は, 加工幅が狭いと 言えども，直線切れ刃に負荷が大きくかかるような加工条件では, びびり振動を発生したり工具が撓む惧れ があり，条件設定に注意を払う必要がある。

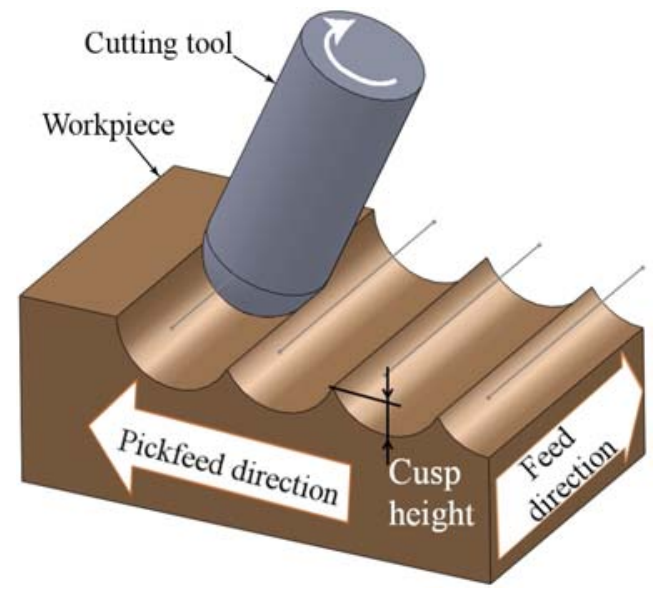

(a) Top edge cutting

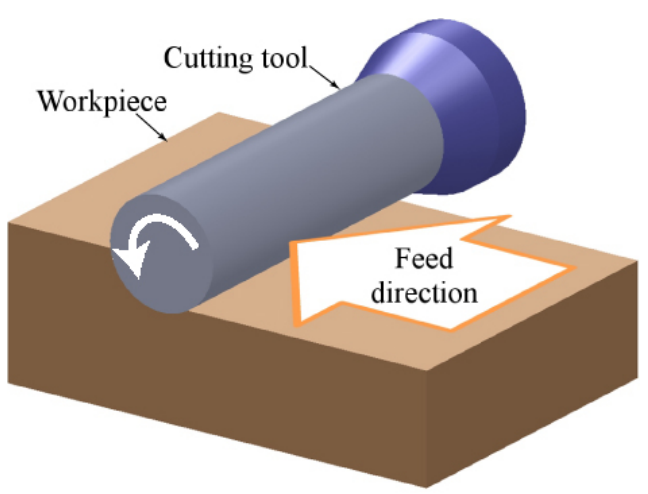

(b) Side edge cutting

Fig. 1 Two kinds of 5-axis control machining

\section{3. 開発した CAM システム}

最初に，目標形状において側面切れ刃で加工できる面の検出を行う。この面はルールドサーフェスと呼ばれる ものであり, 線分の両端が 3 次元空間内の 2 本の曲線上をそれぞれ連続的に移動するとき, その線分の軌跡とし 
て定義される曲面のことである．平面や円柱側面や円錐側面などが例に挙げられる．側面切れ刃を用いた加工で は，面と平行に工具を当て，面をなぞるように加工する工具経路を作成する．その際，工具が被削物と干渉を起 こさないかどうかを考慮に入れる必要がある．以降，工具の包絡形状と被削物が接し，切削加工寸る部分の直線 を “Cutting line” と呼ぶことにする（図 2)．また，荒加工終了後に残存しているカスプを一度で除去すると，除 去体積が大きくなり工具が撓む可能性があるため, 側面切れ刃を用いた仕上げ加工は 3 回に分けて行うこととし た. 具体的には，1回目終了時にはカスプの半分ほどを残しておき，2 回目で目標形状を削り出し，3回目は 2 回 目と同じ工具経路で加工を行い，仕上げ加工とする.

側面切れ刃で加工できない面については，従来通りボールエンドミルの先端切れ刃を用いた加工を行う工具経 路を生成する.

\section{$3 \cdot 1$ ルールドサーフェスの検出}

ルールドサーフェスは線分の軌跡として定義されているため, 面内の全ての点において, 面の一端と他端を結 ぶ直線が存在する．この性質を利用してルールドサーフェスであるかどうか判定することができる．まず，図 3 のように，曲面を三角形で近似し，そのときの誤差が一定量以下となるように，曲面を三角形にメッシュ分割す る. 図3(b)のように, ルールドサーフェスでなければ, 面の内部で直線が折れ曲がる点があり, そこに三角形の 頂点が存在する. したがって本 CAM システムでは, すべての三角形の頂点が面のエッジ上に存在するかどうか を確認し，全ての頂点がエッジ上にあれば，ルールドサーフェスであると判定する.

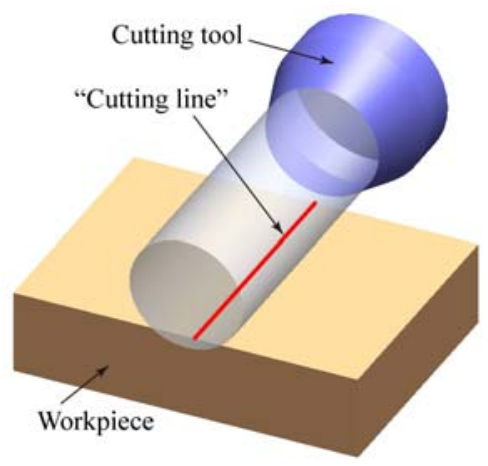

Fig. 2 Definition of "Cutting line”

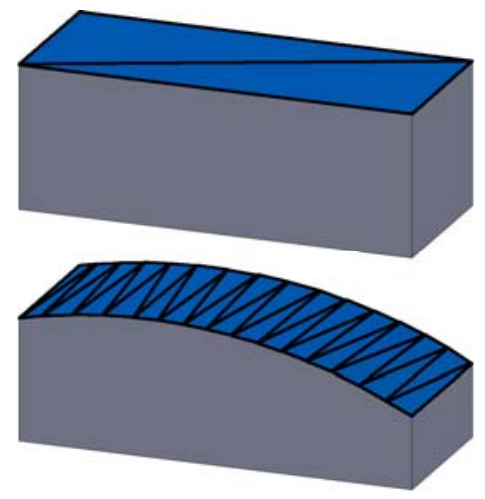

(a) Ruled surfece

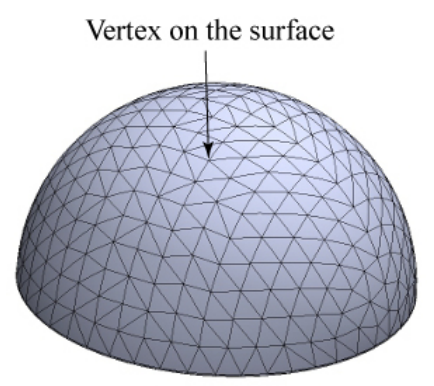

(b) Not ruled surfece

Fig. 3 Tessellated surfaces

\section{$3 \cdot 2$ 側面切れ刃を用いた工具経路生成}

ルールドサーフェスと判定された面に対して側面切れ刃を用いた工具経路を生成する. 手順は図 4 に示すよう である.

(a) ルールドサーフェスから一定距離オフセットした曲面を生成する.

(b) オフセットサーフェスのエッジを曲線と直線に分類する. これはエッジ (赤線) の長さと, エッジの端 点間を結ぶ直線（青線）の長さを比較し，2つの長さが等しければエッジは直線，異なればエッジは曲 線であると判断する.

(c) 曲線上に点を生成する.

(d) それぞれの点に対して面と平行な直線を求めると, それが側面切れ刃を用いた加工の工具軸ベクトルと なる。

なお，図 3(a)上のように平面の場合はエッジの長さを比較し，短い方のエッジと並行になるように工具軸を選択 する. 実際の加工時には工具は図 4(c)で得られた点間を直線補間で移動する. そのため, 曲線を直線で近似した ときの誤差が一定の值以下となるように手順(c)で曲線の分割を行う．誤差の值を変化させることにより，加工の 精度を変化させることが可能である. なお, 図 4(d)で得られた直線の長さに基づいて, 側面切れ刃を用いた加工 に必要な工具の寸法を求めている. 
複雑な形状を加工しようとすると, 被削物と工具が干渉を起こす場合が考えられる．これを回避し，最適な工 具経路を得るために，すべての工具姿勢において評価を行う必要がある．そこで図 5 のように，工具軸上の多数 の点において, その位置での工具半径と, 工具軸から被削物までの最短距離とを比較する(11). 被削物までの距離 の方が長ければ，工具と被削物は干渉していないことになる．また，1つの “Cutting line” に対して干渉が発生し ていない工具姿勢が複数考えられる場合は, 工具軸から被削物までの距離の総和で評価し, 最も長くなるものを 工具姿勢として選択する.

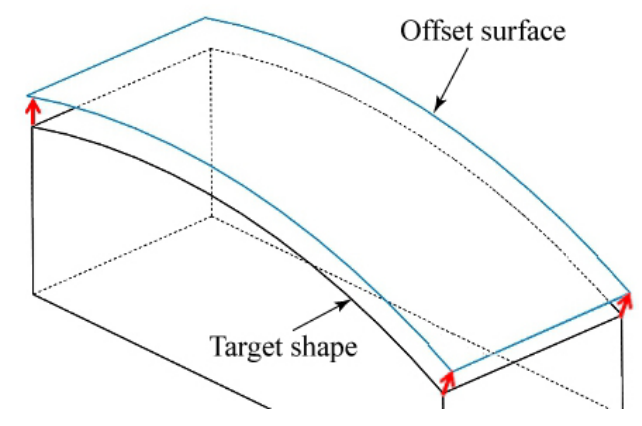

(a) Generation of offset surface

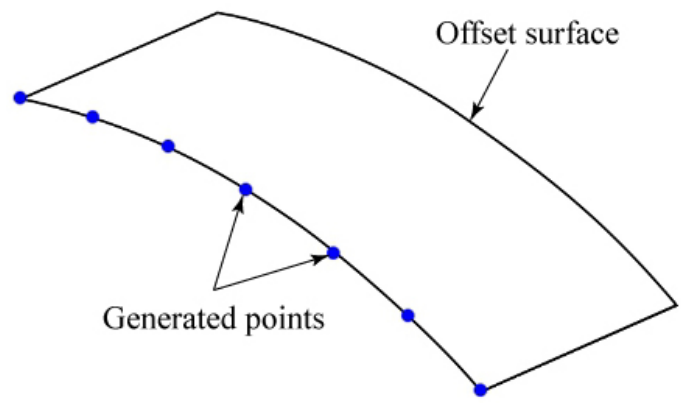

(c) Generation of points on the edge of offset surface

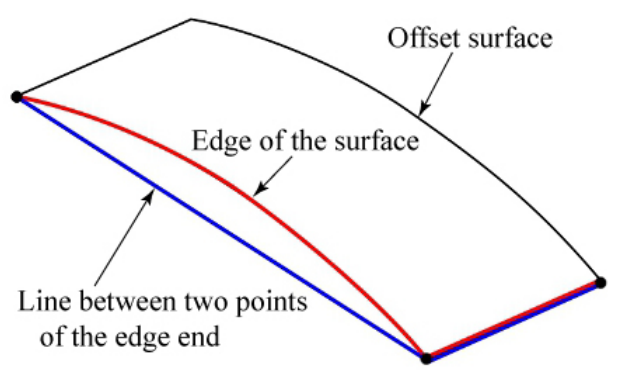

(b) Comparison of lengths shown in red and blue lines

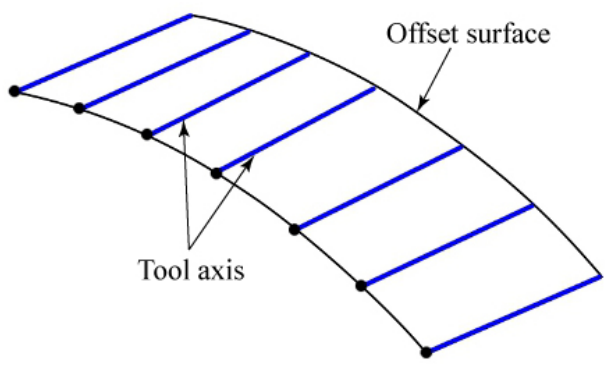

(d) Determination of tool axis vectors

Fig. 4 Procedure of determining tool axis

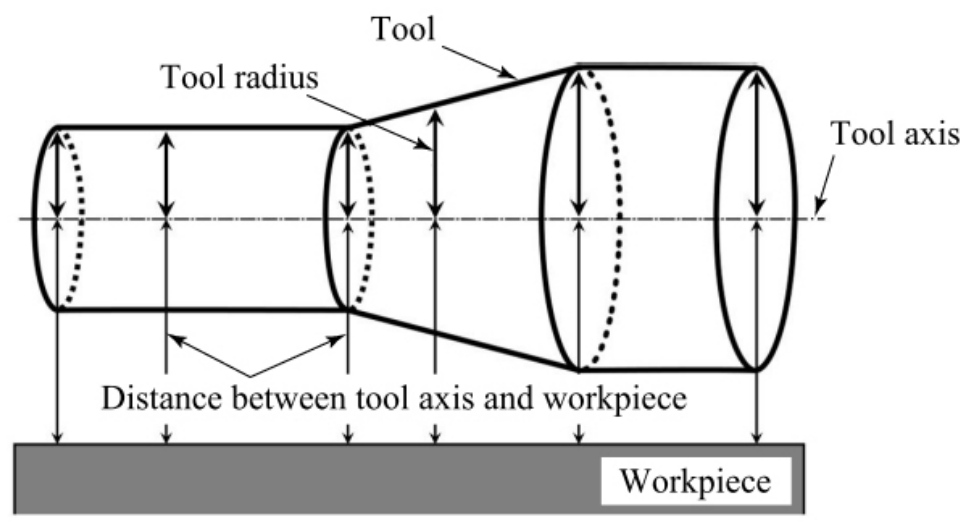

Fig. 5 Method of collision check

\section{$3 \cdot 3$ 先端切れ刃を用いた工具経路生成法}

ルールドサーフェスではあるが工具と被削物の干渉を避けることができない場合や，そもそも目標形状がルー ルドサーフェスでない場合は，側面切れ刃を用いた仕上げ加工を行うことができない．このような場合において は，従来通り先端切れ刃を用いて加工寸る. 側面切れ刃による工具経路作成時と同じように, 工具軸上の多数の 点において, 工具軸から加工物の面までの距離と, 工具半径とを比較して, 工具が被削物と干渉を起こさないよ うな工具姿勢を考える. その後, 可能な工具姿勢の中から, 初めに設定した工具姿勢を大きく変えないで加工で きる工具姿勢を選び, 工具経路を生成する ${ }^{(12)(13)}$. 


\section{4. メビウスの輪の加エ}

\section{4・1 加工条件}

開発した CAM システムの有効性を確認するために超精密多軸制御加工機（FUNUC ROBOnano Ui）を用いて加 工実験を行った。この加工機は摩擦のないサーボ，並進軸 X, Y, Z の 3 軸と，回転軸 B, Cの 2 軸の計 5 軸から 構成されている超精密マシニングセンタである，特徵としては，各軸がユニット化されているため，超精密加工 に必要な剛性と良好な運動性をもつこと, 旋盤加工機としてだけでなく C 軸テーブル上にスピンドルを設置して フライス加工機として,さらに B 軸上に A 軸を付加することで同時 6 軸制御加工機として用いることも可能であ る. $\mathrm{X}$ 軸上に並進 $\mathrm{Y}$ 軸と回転 B 軸, $\mathrm{Z}$ 軸上に回転 $\mathrm{C}$ 軸が搭載されており, サーボモータも含め全軸の褶動面に静 圧空気軸受を採用している。この加工機の概念図を図 6, 仕様を表 1 に示す.

目標形状は図 7 のメビウスの輪とし，材質は快削黄銅とした。荒加工は工具先端切れ刃を用いた 3 軸制御加工 を行い，その工具経路は市販の CAM システム ESPRIT を用いて生成した. 工具経路を生成する際，目標形状と の誤差が最大 $1 \mu \mathrm{m}$ となるようにした. 仕上げ加工は開発したCAM システムを用いて目標形状の面を判別し, 先 端切れ刃に加えて側面切れ刃を用いる工具経路で 5 軸制御加工を行った.

加工に影響を与える誤差の要因としては，工具形状，セッティング，加工機，加工条件，材料，環境，制御な どが挙げられるが, 特に超精密多軸加工においては, セッティング時の誤差が大きな要因となる. 工具中心と B, C 軸回転中心軸の位置決めを行う場合, マイクロスコープなどを用いて目視と手動で行うには限界があり，位置 決め誤差を解消できない可能性が高い. そこでB軸回転中心は測定值に基づいて加工機のセッティングを修正し, C 軸回転中心は加工機のセッティングを修正するのではなく測定值に基づいて NCデータを補正することにより， 工具のセッティング誤差の補正を行った ${ }^{(14)}$. また, 被削物や工具を加工途中に付け替えると, 誤差が発生し加工 面品質に悪影響を与える，そのため，本実験では，先端切れ刃を用いる荒加工から先端切れ刃と側面切れ刃を使 い分ける仕上げ加工までの工程において，工具を付け替えなくて済むよう先端は球状で側面切れ刃に十分な長さ のあるボールエンドミル工具を使用した. 工具の寸法を図 8 に示す. 工具の材質は超硬で，2枚刃，孙じ角は 30 度である.

荒加工においてはピックフィード $30 \mu \mathrm{m}$ ，切込み深さ $30 \mu \mathrm{m}$ で工具経路を生成し，仕上げ加工においては目標 形状との誤差が $100 \mathrm{~nm}$ 以下となるように工具経路を生成した. また, 荒加工・仕上げ加工ともに, 工具の主軸 回転数 30,000 rpm, 切削時の工具の送り速度は $30 \mathrm{~mm} / \mathrm{min}$ で加工した.

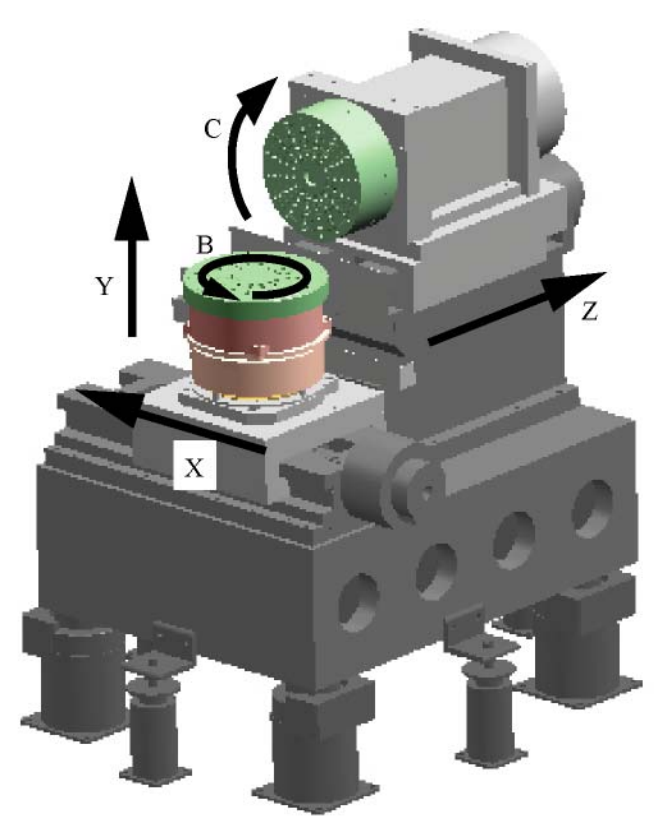

Fig. 6 Structure of FUNUC ROBOnano Ui
Table 1 Specification of ROBOnano Ui

\begin{tabular}{|c|c|c|}
\hline \multirow{4}{*}{ Stroke } & $\mathrm{X}$ axis & $200 \mathrm{~mm}$ \\
\hline & $\mathrm{Y}$ axis & $20 \mathrm{~mm}$ \\
\hline & $\mathrm{Z}$ axis & $100 \mathrm{~mm}$ \\
\hline & $\mathrm{B}, \mathrm{C}$ axis & 360 dig \\
\hline \multirow{2}{*}{ Resolution } & $\mathrm{X}, \mathrm{Y}, \mathrm{Z}$ axis & $1 \mathrm{~nm}$ \\
\hline & A, B, C axis & $10 \mathrm{e}-5 \mathrm{deg}$ \\
\hline \multicolumn{2}{|c|}{ Positioning accuracy } & $5 \mathrm{~nm}$ \\
\hline \multicolumn{2}{|c|}{ Repeatability } & $1 \mathrm{~nm}$ \\
\hline \multicolumn{2}{|c|}{ X, Z linearity } & $30 \mathrm{~nm} / 200 \mathrm{~mm}$ \\
\hline \multicolumn{2}{|c|}{$\mathrm{C}$ maximum revolution } & 1500 rpm \\
\hline \multirow{2}{*}{$\begin{array}{c}\text { C rotational } \\
\text { accuracy }\end{array}$} & Radial & $\pm 0.01 \mu \mathrm{m}$ \\
\hline & Axial & $\pm 0.01 \mu \mathrm{m}$ \\
\hline
\end{tabular}




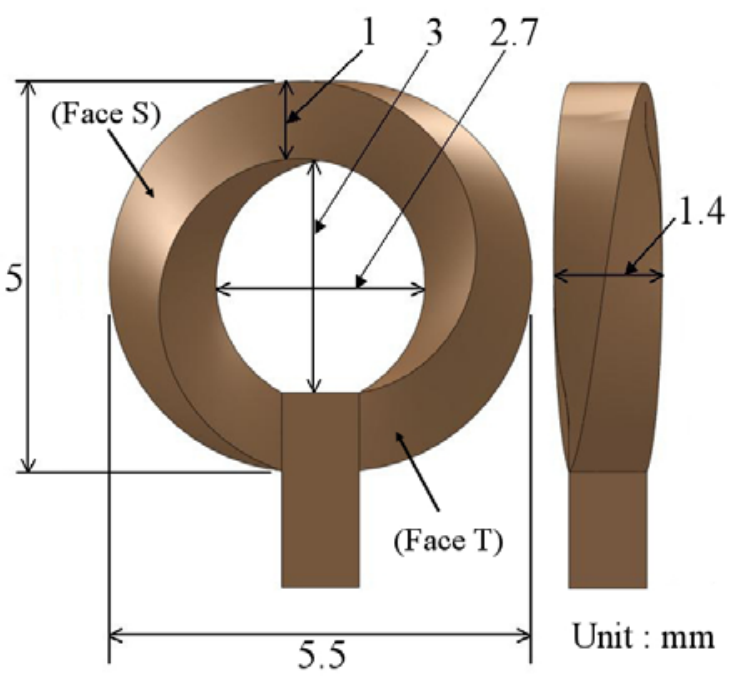

Fig. 7 Möbius ring as a target shape

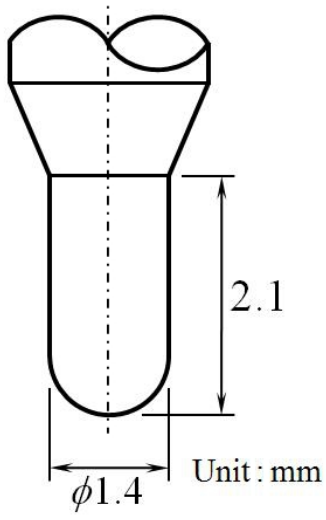

Fig. 8 Cutting tool

\section{$4 \cdot 2$ 加工結果と考察}

開発した CAM システムを用いて，目標形状に含まれる面の中で側面切れ刃を用いて加工できる面，ボール形 状の先端切れ刃を用いて加工寸る面を検出した，メビウスの輪は全ての面がルールドサーフェスであるが，工具 と被削物の干渉などを考慮し，図 9 に示寸ように側面切れ刃と先端切れ刃を使い分けている. それぞれの切れ刃 で加工寸る面の 1 つを面 S と面 $\mathrm{T}$ とする。側面切れ刃で加工できる面について，工具と被削物の干涉を考慮に入 れた工具経路を生成した結果の一例が図 10 である. 図のように，工具と被削物が干渉を起こさずに面をなぞるよ

うに工具が移動していることが分かる.

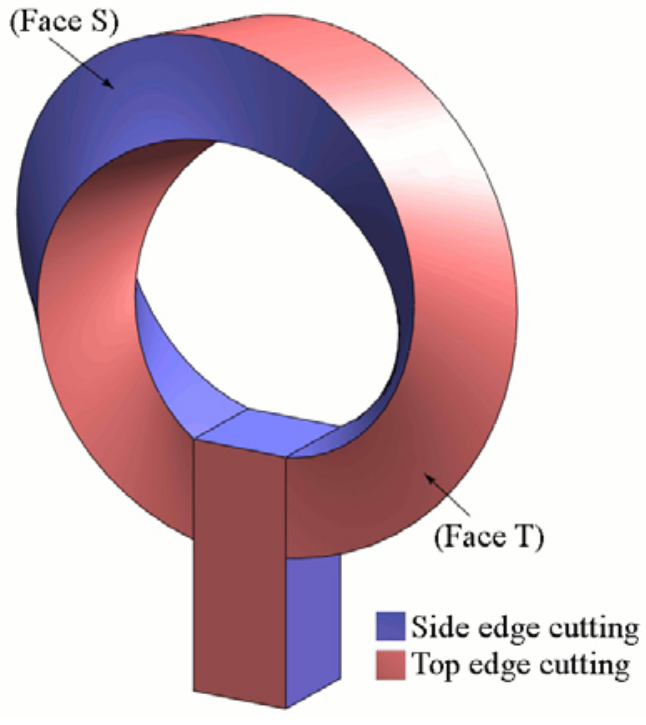

Fig. 9 Decision of cutting edge

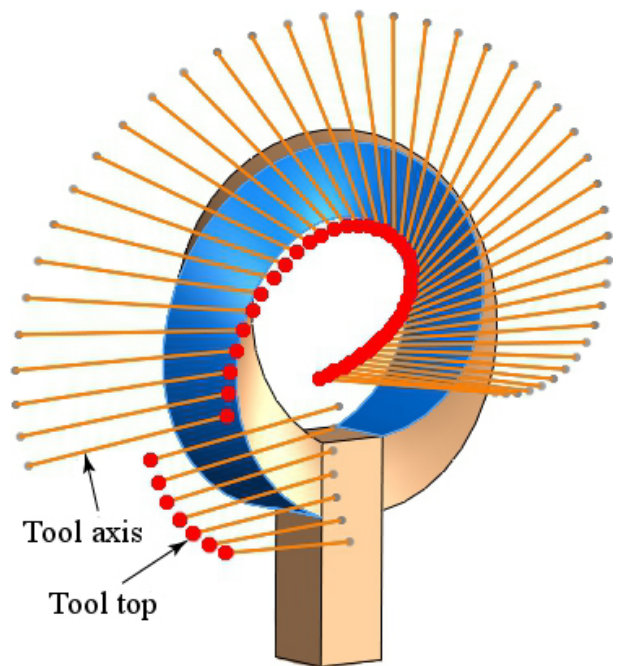

Fig. 10 Example of side edge cutting tool path

また, 加工結果を図 11 に, 側面切れ刃を用いて仕上げ加工した面と側面切れ刃を用いて仕上げ加工した面をマ イクロスコープ(KEYENCE VW-6000)で拡大して観察した様子を図 12 に示す. 先端切れ刃を用いた場合と比較し て，側面切れ刃を用いた場合において大きなカスプは確認できない.さらに図 9 に示した面 $\mathrm{S}$ と面 $\mathrm{T}$ の仕上げ加 工に要した時間を表 2 に示寸。メビウスの輪のリング部分の 4 つの面の面積は多少異なるが，リング部分の $4 つ$ の面を先端切れ刃で仕上げ加工を行った場合，加工時間は面 $\mathrm{T}$ の加工に要した時間の 4 倍の 6 時間程度必要にな ると予想される。しかし，開発した CAM システムを用い側面切れ刃を積極的に利用した結果，約 3 時間に短縮 できた（表 3). なお，本研究では測定が困難なため表面粗さに関する考察は行なっていない. 


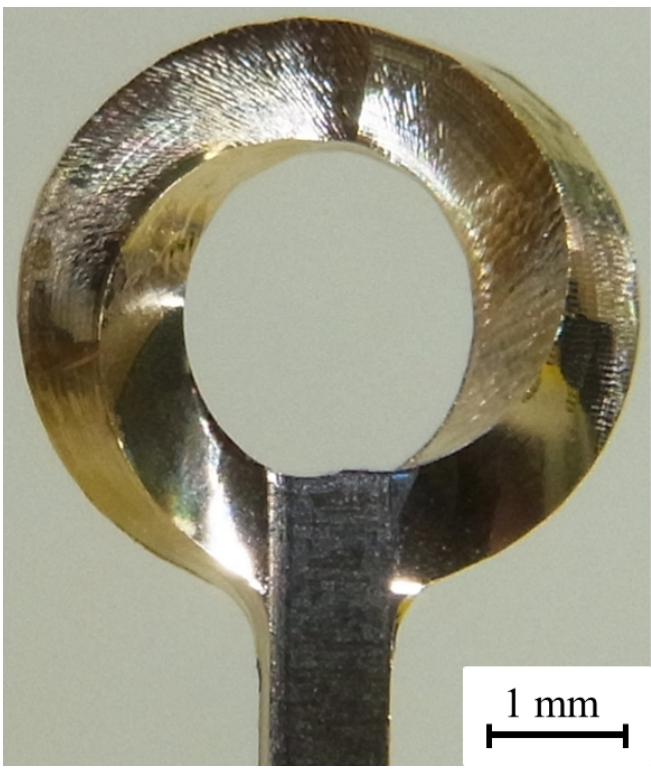

(a) Front view



(b) Side view

Fig. 11 Machined result

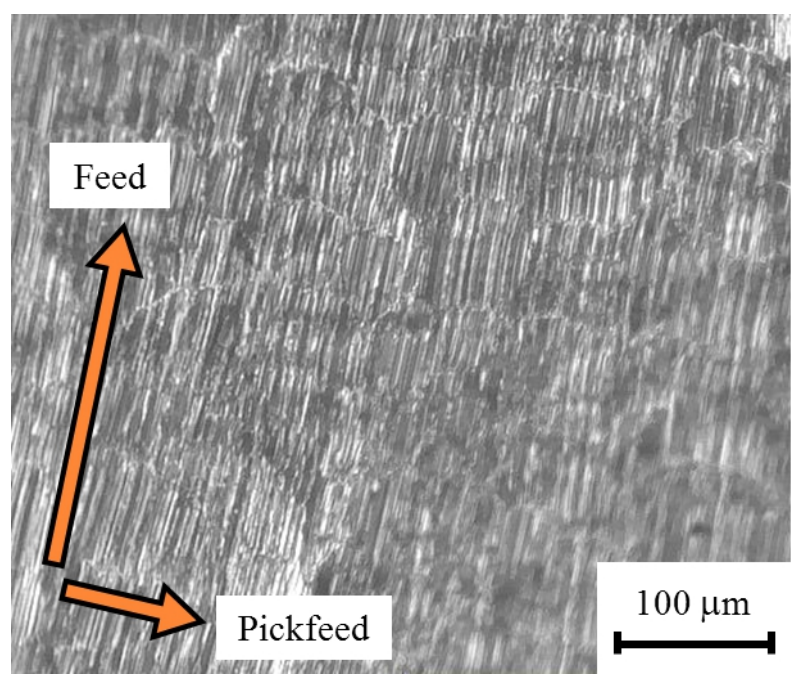

(a) Top edge cutting

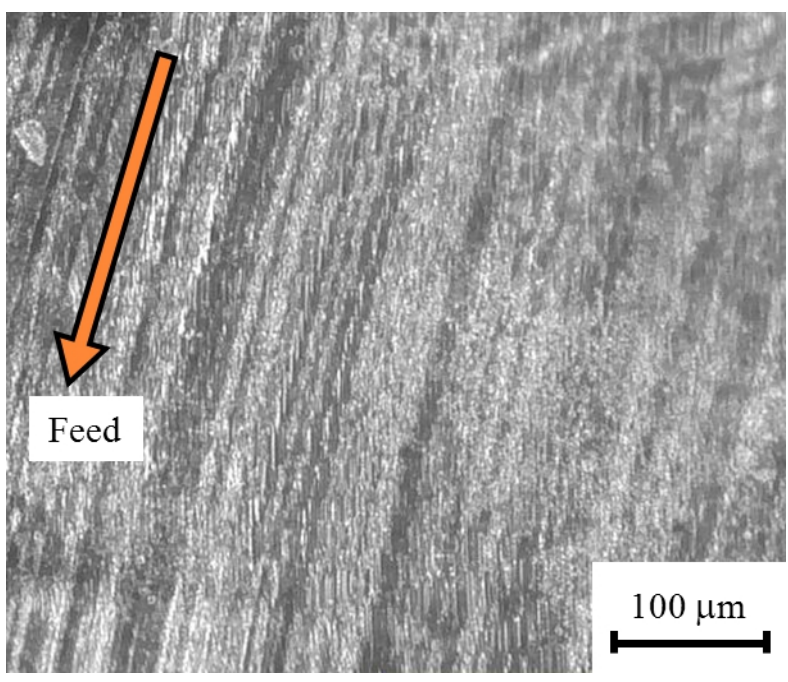

(b) Side edge cutting

Fig. 12 Machined surface

Table 2 Finish cutting time

\begin{tabular}{c|c}
\hline Cutting edge & $\begin{array}{c}\text { Actual } \\
\text { cutting time }\end{array}$ \\
\hline Side edge (Face S / $11.79 \mathrm{~mm}^{2}$ ) & $4.5 \mathrm{~min}$ \\
\hline Top edge (Face T / $13.56 \mathrm{~mm}^{2}$ ) & $91 \mathrm{~min}$ \\
\hline
\end{tabular}

Table 3 Comparison of total finish cutting time

\begin{tabular}{c|c}
\hline Cutting edge & Calculated total time \\
\hline Only top edge & Face $\mathrm{T} * 4=6$ hour \\
\hline Both side and top edge & (Face $\mathrm{S}+$ Face $\mathrm{T}$ ) ${ }^{*}=3$ hour \\
\hline
\end{tabular}




\section{5. 結}

本研究では, 複雑な形状を要素に分割することなくそのまま処理することで, 工芸品のような付加価值の高い 製品を短時間で加工することを目的とし，加工物に含まれるルールドサーフェスを検出し，その面に対しては回

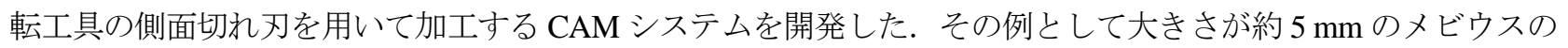
輪を加工した結果, 目標形状通りの加工ができ, さらに従来の先端切れ刃を用いた加工方法と比較して加工時間 を大幅に短縮することができた。これより本研究で開発した CAM システムの有用性を確認することができた.

\section{謝 辞}

本研究の一部は科学研究費補助金（No. 23360069）により行われた．また, CAM システム ESPRIT はDP Technology 社より貸与して頂き，加工実験に用いた超精密加工機は株式会社ファナックより提供頂いた．記して 謝意を表する.

\section{文献}

（1）河口泰大，中本圭一，石田 徹，竹内芳美，“複合加工機による鎖形状の巧妙加工”, 日本機械学会論文集 C 編, Vol. 76, No. 771 (2010), pp. 3112-3118.

(2) Noriyuki Natsume, Keiichi Nakamoto, Tohru Ishida, Yoshimi Takeuchi, "Dexterous Machining of Complicated Shape Consisting of Bended Columns", Proceedings of 14th International Conference on Mechatronics Technology, Icho-kaikan, Osaka, Japan (2010), pp. 24-27.

（3）濱田大地, 中本圭一, 石田 徹, 竹内芳美, “入れ子を有する複雑形状の巧妙加工”, 日本機械学会論文集 C 編, Vol. 77, No. 780 (2011), pp. 3127-3136.

(4) Y. Takeuchi, H. Yonekura, K. Sawada, "Creation of 3-D Tiny Statue by 5-Axis Control Ultraprecision Machining", Computer-Aided Design, Elsevier, Vol.35, No.4 (2003) 403-409.

（5）佐々木崇, 園 真, 石田 徹, 河合知彦, 竹内芳美, “5 軸制御超精密フライス加工による 3 次元微細彫像の創成”, 精密工学会誌，Vol. 74, No. 1 (2007), pp. 1256-1260.

(6) Y. Takeuchi, K. Sawada, T. Sata, "Manufacture of Micropropeller by Means of Ultraprecision Milling Machine”, Journal of Robotics and Mechatronics, Vol.9, No.6 (1997), pp. 475-479.

（7） 大場貴信, 中本圭一, 石田 徹, 竹内芳美, “5 軸制御加工用 CAPP/CAM システムの開発一3 次元微小部品加工へ の適用一”, 精密工学会誌, Vol. 76, No. 1 (2010), pp. 90-95.

(8) K. Nakamoto, T. Ishida, N. Kitamura, Y. Takeuchi, "Fabrication of Microinducer by 5-Axis Control Ultraprecision Micromilling”, CIRP Annals - Manufacturing Technology, Vol. 60, No. 1 (2011), pp. 407-410.

（9）竹内芳美, 森重功一, 横山信人, 久木達也, “側面切れ刃工具による 5 軸制御加工”, 精密工学会誌, Vol. 60, No. 8 (1994), pp. 1164-1168.

(10) 竹内芳美, 長坂 学, 森重功一, “ボールエンドミルの先端切れ刃・側面切れ刃を併用した 5 軸制御加工”, 精密工 学会誌, Vol. 61, No. 4 (1995), pp. 561-565.

（11）竹内芳美, 清水弘幸, 出村 健, 渡辺隆弘, 伊藤哲也, “ソリッドモデルに基づく 5 軸制御加工”, 精密工学会誌, Vol. 56, No. 11 (1990), pp. 2063-2068.

(12) 森重功一, 加瀬究, 竹内芳美, “C-Space を用いた 5 軸制御加工のための工具経路生成法”, 精密工学会誌, Vol. 62, No.12 (1996), pp. 1783-1787.

（13）山田 誠，田中文基，近藤 司，岸浪建史，“5 軸 NC 工作機械による主軸傾斜曲面加工法に関する研究（第 3 報） ーボールエンドミル傾斜加工における切削力解析による工具姿勢評価一”, 精密工学会誌, Vol. 73, No. 5 (2007), pp. 563-567.

（14）園 真, 石田 徹, 寺本孝司, 榎本俊之, 竹内芳美, “超精密 5 軸制御加工におけるセッティング誤差の一般化補 正法”, 精密工学会誌, Vol.73, No. 10 (2007), pp. 1154-1158. 